\title{
The Meaning of homoios (önoĩos) in Theogony 27 and Elsewhere
}

\section{Citation}

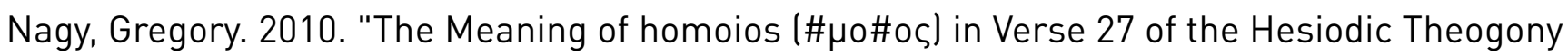
and Elsewhere." In Allusion, Authority, and Truth: Critical Perspectives on Greek Poetic and Rhetorical Praxis, eds. Phillip Mitsis and Christos Tsagalis, 153-167. Trends in Classics 7. Berlin and New York: Walter De Gruyter.

\section{Published Version}

doi:10.1515/9783110245400.1.153

\section{Permanent link}

http://nrs.harvard.edu/urn-3:HUL.InstRepos:14528174

\section{Terms of Use}

This article was downloaded from Harvard University's DASH repository, and is made available under the terms and conditions applicable to Other Posted Material, as set forth at http:// nrs.harvard.edu/urn-3:HUL.InstRepos:dash.current.terms-of-use\#LAA

\section{Share Your Story}

The Harvard community has made this article openly available.

Please share how this access benefits you. Submit a story.

\section{Accessibility}




\section{The meaning of homoios (ópoĩos) in verse 27 of the Hesiodic Theogony and elsewhere}

\section{Gregory Nagy}

[Originally printed in Allusion, Authority, and Truth: Critical Perspectives on Greek Poetic and Rhetorical Praxis (ed. Phillip Mitsis and Christos Tsagalis; Trends in Classics vol. 7; Berlin and New York 2010) 153-167. The page-numbers of the printed version are embedded within brackets in this electronic version: for example, $\{153 \mid 154\}$ marks where p. 153 stops and p. 154 begins.]

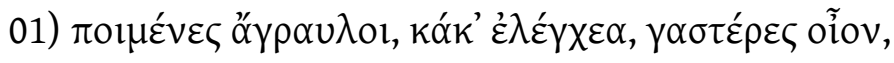

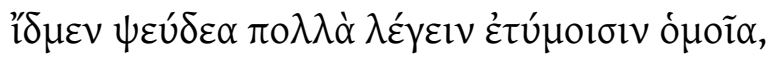

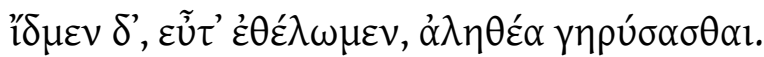

Shepherds camping in the fields, base objects of reproach, mere bellies! We know how to say many deceptive things looking like genuine things, but we also know how, whenever we wish it, to proclaim things that are true.

Hesiodic Theogony 26-28

According to the Hesiodic Theogony, these words are spoken by the Muses themselves to Hesiod, whom they encounter while he is tending sheep in the foothills of Mount Helicon. In

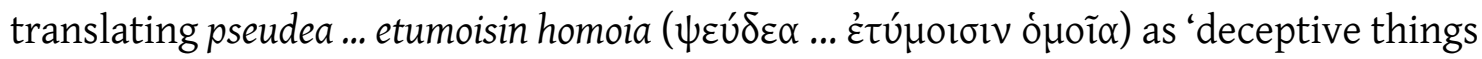
[pseudea] looking like genuine [etuma] things' at verse 27 of the Theogony, I am in agreement with a wide range of interpreters who have studied this verse, including Pietro Pucci, who translates the relevant wording this way: "lies that look like truths' ${ }^{1}$ and 'menzogne simili alla

\footnotetext{
${ }^{1}$ Pucci 1977:9.
} 
realtà'. ${ }^{2}$ It has been argued, however, that the adjective homoios (ómoĩoc), as used here and elsewhere in Hesiodic and Homeric diction, should be translated not as 'looking like' or 'similar to' or 'resembling' but only as 'equivalent to' or 'equal to [in some respect]. ${ }^{3}$ According to this argument, "ónoĩos [homoios] seldom - if ever - denotes resemblance, much less resemblance so close as to be deceptive." ${ }^{\prime 4}$ Re-examining the etymology and the $\{153 \mid 154\}$ contexts of this adjective in both Homeric and Hesiodic diction, I counterargue that the translation of homoios (ónoĩoৎ) as 'looking like' or 'similar to' or 'resembling' is valid.

First, I consider the etymology.

From the standpoint of Indo-European linguistics, the Greek adjective homoios (ónoĩos) derives from a prototypical form *somo-, with the meaning 'same as'. ${ }^{5}$ The English adjective same is derived from this same prototypical form. Another derivative is the Latin adjective similis, meaning 'same as' or 'similar to'. In the usage of both Latin similis and Greek homoios (ópoĩo), the same semantic principle applies: for $X$ to be similar to $Y$ is for it to be the same as $Y$ in some respect, which is $Z$. Here I am agreeing with Pucci when he says that "ónoĩos can suggest both similarity and identity." ${ }^{\prime 6}$ Further, for $X$ to be the same as $Y$ is for it to be one with $Y$ in respect to Z. That is because the Indo-European root *som- of *somo- 'same as' means 'one', as we see in such forms as the Latin adverb semel 'one time'. And the idea of 'one' in words like English same has to do with an act of comparing. When we compare things, what is the 'same as' something else in some respect becomes 'one with' that something in that respect, as we see in the usage of Latin similis. What is similis 'similar' to something else in some respect is 'one with' that

\footnotetext{
${ }^{2}$ Pucci 2007:27.

${ }^{3}$ Heiden 2007, following Leclerc 1993:212-16. Heiden p. 154n4 gives a list of those who have translated 'looking like' or 'similar to' or 'resembling', including Nagy 1990:45. See also Nagy 2009:276.

${ }^{4}$ Heiden 2007:155n7.

${ }^{5}$ Chantraine 2009 s.v. óuós.

${ }^{6}$ Pucci 1977:9. Heiden 2007:154n4 explicitly disagrees with this statement of Pucci. See also Pucci 2007:63, 68-69.
} 
something in that respect. Similarly in the case of the Greek adjective homoios (ónoioc), it refers to something that is 'one with' and therefore 'the same as' something else in some respect. And, as we will see later, if something else is not the same, then it is alloios ( $\left.\dot{\alpha} \lambda \lambda_{0} \tilde{i o c}_{0}\right)$ 'a different kind', which is the opposite of homoios (ónoĩoc) or 'the same kind'. As we will also see later, the extension -ios (-10૬) of the two adjectives homoios (ópoĩoc) 'the same kind' and alloios

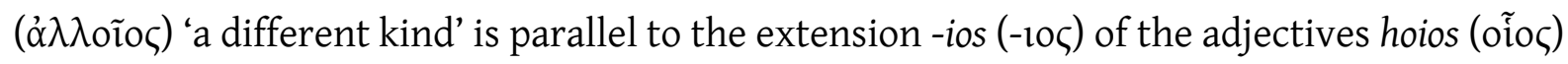

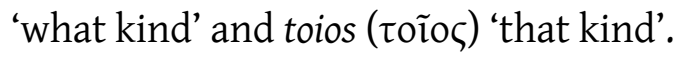

Next, I consider the contexts of homoios (ómoĩoৎ) in Homeric and Hesiodic diction.

I start with a basic observation. When homoios (ópoĩoৎ) as an adjective describing a noun X is combined with the dative case of a noun $Y$, then $X$ is 'the same as' $Y$ with respect to $Z$. Another way to say it is that $\mathrm{X}$ is 'equal to' $\mathrm{Y}$ with respect to $\mathrm{Z}$. And the ' $\mathrm{Z}$ ' can be indicated in any one of three different ways: an accusative of respect, an epexegetical infinitive, or a prepositional phrase. ${ }^{7}$ Here are three examples that match these three different ways (numbers 02, 03, and 04): $\{154 \mid 155\}$

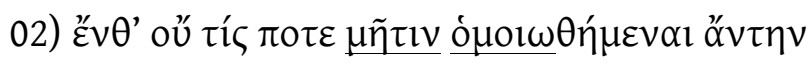

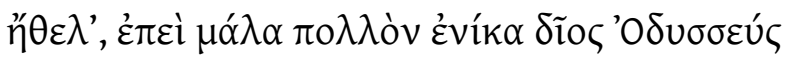

Back then, there was nobody who would set himself up as equal to [homoios] him [= Odysseus $]$ in craft, no, nobody would be willing to do so, since radiant Odysseus was so much better.

\footnotetext{
${ }^{7}$ These three categories have been noted by Heiden 2007:156.
} 


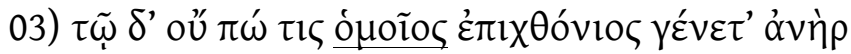

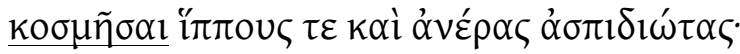

Never before had there been a mortal man who was equal to [homoios] him [=

Menestheus]

in marshalling the horse-drawn chariot teams and the shield-bearing warriors.

Iliad II 553-554

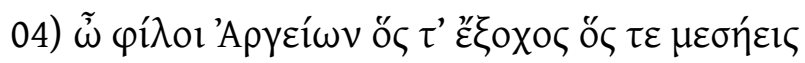

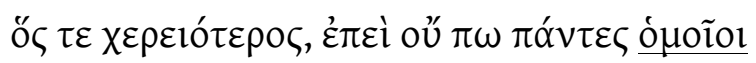

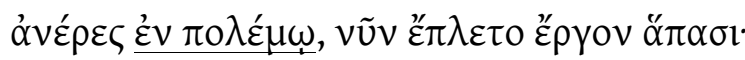

My dear friends! You who are top-rank, and you who are middle-rank, and you who are of lower rank - I say this because it has never yet happened that all men are equal [homoioi] men in war - now is the time when everybody has work to do.

Iliad XII 269-271

As we see from each of the three examples I have just quoted, each occurrence of homoios, which I translated each time as 'equal', has to do with an act of comparing, where X is compared to $Y$ in respect to $Z$. And, in each of these examples, the point that is being made is that someone is superior to all others, who therefore cannot be that someone's equal.

Claims of superiority can be contested, however, as we see in the following three examples (numbers 05, 06, and 07):

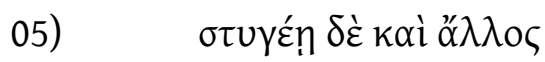




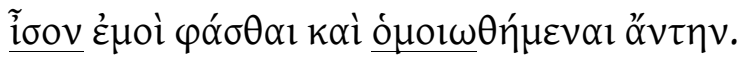

... so that any one else will draw back

from saying that he is equal to [isos] me [=Agamemnon] and from making himself equal to [homoios] me face to face.

Iliad I 186-187

$\{155 \mid 156\}$ Here we see Agamemnon in the act of showing off his political power to Achilles and threatening to show off that same power, which is based on his social status, to anyone else who dares to challenge him. The adjective isos here, which means 'equal', is synonymous with homoios, which I translate also as 'equal' here. The point being made by the figure of Agamemnon is that nobody is his equal, not even Achilles. To put it another way, we can say that Agamemnon is claiming that nobody is his peer, that he is peerless. But this claim of Agamemnon can be contested, as we see from the next example, featuring words spoken by the figure of Nestor:

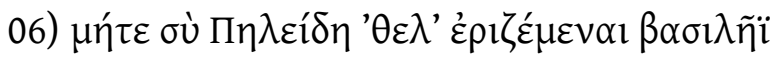

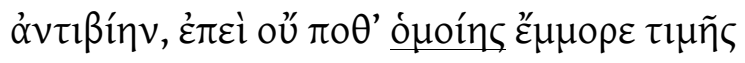

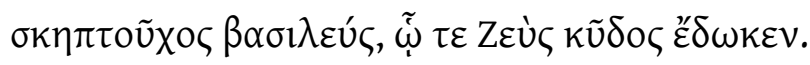

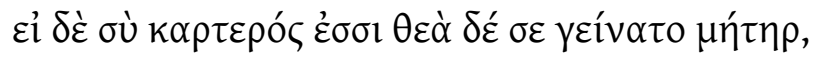

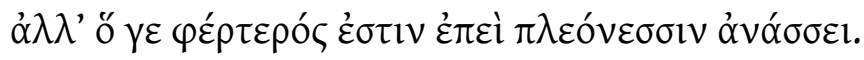

Don't you, son of Peleus, be quarrelling with the king, force against force, since it is never an equal [homoiē] thing, I mean, the rank inherited 
by a king holding the scepter, to whom Zeus has given a luminous sign of sovereignty.

Even if you [= Achilles] are as mighty as you are, born of a goddess, nevertheless, he [= Agamemnon] is superior in status, since he rules over more subjects.

Iliad I 277-281

By implication, Nestor here is recognizing that Agamemnon is actually inferior to Achilles in warfare, even though he is superior in social status. So Agamemnon is not peerless, as he claims to be. Achilles himself questions Agamemnon's claim to be peerless, laying claim to his own social status as a peer of Agamemnon:

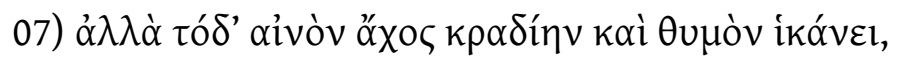

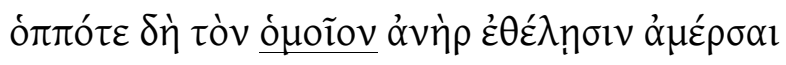

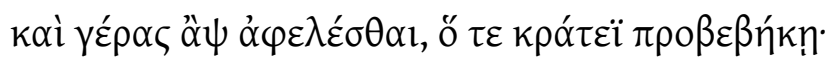

But I have this terrible sorrow that has come over my heart and spirit, seeing as I do that the man [= Agamemnon] is trying to deprive a man who is equal to [homoios] him and to take away the prize of this man [= Achilles], just because he [= Agamemnon] is ahead in power.

Iliad XVI 52-54

$\{156 \mid 157\}$ In the last example, equality in respect to social status is seen as an acceptable alternative to superiority. Equality in most other respects, however, is merely a foil for the 
superiority of whatever or whoever is being highlighted. Here are two examples featuring the word homoios (numbers 08 and 09):

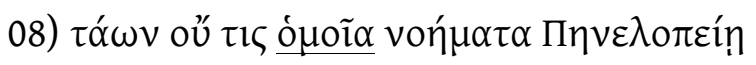

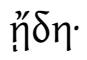

Of all these women, not one knew thoughts equal to [homoia] the thoughts that Penelope knew.

Odyssey ii $121-122$

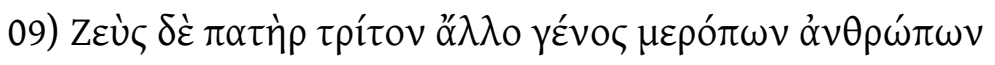

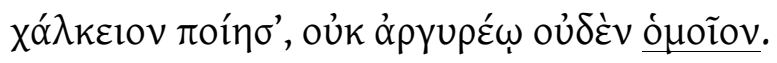

Then Zeus the father made a third generation of radiant humans, making it a bronze one, not at all equal to [homoion] the silver one [that came before].

Hesiodic Works and Days 143-144 In the first of these two examples, Penelope is incontestably superior to the other women, and, in the second, the bronze generation is incontestably inferior to the silver.

Continuing my survey of examples where the adjective homoios is used in comparisons, I now turn to a distinct subset of examples that will be basic for my argumentation. In the examples that belong to this subset, the act of comparing by way of the word homoios takes the form of a simile. When $\mathrm{X}$ is said to be homoios to $\mathrm{Y}$ within the framework of a simile, the comparison allows for translating not only as ' $\mathrm{X}$ is equal to $\mathrm{Y}$ ' but also as ' $\mathrm{X}$ is similar to $\mathrm{Y}$ ' or as 
' $\mathrm{X}$ resembles $\mathrm{Y}$ ' or even as 'X looks like $Y$ '. That is because, as we will now see, the making of a simile is primarily the making of a visual comparison. And what I have just said applies not only to

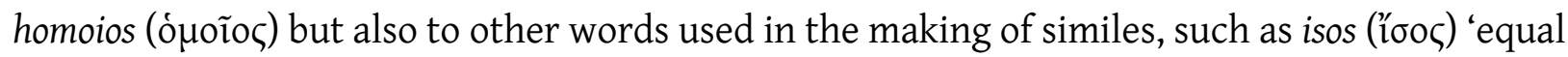

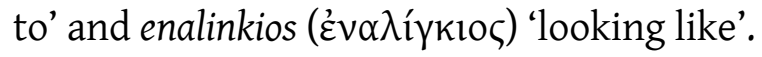

Before I show examples of homoios (ónoĩos) used in similes, I propose to show two comparable examples of isos ('̋oৎ) 'equal to'. I take these two examples from a study of mine that centers on the making of similes by way of this adjective isos in sacred contexts where a comparison is being made between a human and a divinity. The sacred context in both examples is a ritual. Specifically, it is a wedding. In the context of such a ritual, the comparison between the human and the $\{157 \mid 158\}$ divinity is visualized as a fusion of identities between the two. ${ }^{8}$ In the

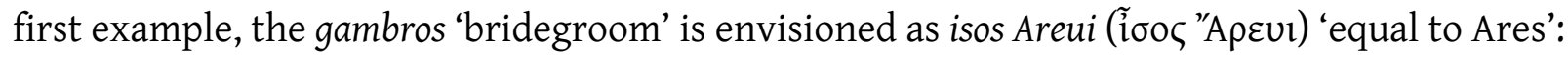

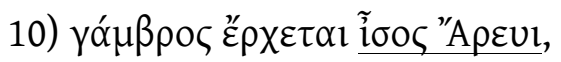
óv $\delta \rho \circ \varsigma \mu \varepsilon \gamma \alpha \dot{\alpha} \lambda \omega \pi \sigma^{\prime} \lambda v \mu \varepsilon \dot{\zeta} \zeta \omega v$.

Here comes the bridegroom, equal to [isos] Ares, bigger than a big man, much bigger.

Sappho F 111.5-6

In the second example, the bridegroom is envisioned more generally as isos theoisin ('øoৎ Өćoløıv) 'equal to the gods':

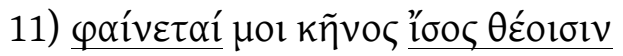

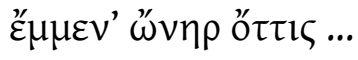

\footnotetext{
${ }^{8}$ Nagy 2007:28-29.
} 
He appears [phainetai] to me, that one, to be equal to [isos] the gods, that man who ...

Sappho F 31.1-2

In this second example, the envisioning is expressed by the word phainetai ( $\varphi \alpha i v \varepsilon \tau \alpha l)$ 'he appears'. Appearances become realities here, since phainetai means not only 'he appears' but also 'he is manifested in an epiphany', and this epiphany is felt as real. ${ }^{9}$

Just as the bridegroom can be equated with the god Ares in the wedding songs of Sappho, the bride can be equated with the goddess Aphrodite..$^{10}$ Relevant to the second of these two equations is the Greek word that we translate as 'bride' - which is numphē in Homeric usage and numpha in the poetic dialect of Lesbos, as in Sappho F 116. In my earlier study, I made the following relevant observations about numphe / numpha:

This word, as we can see from its Homeric usage, means not only 'bride' but also 'goddess' - in the sense of a local goddess as worshipped in the rituals of a given locale. And, as we can see from the wedding songs of Sappho, the numphe is perceived as both a bride and a goddess at the actual moment of the wedding. Similarly, the bridegroom is perceived as a god at that same moment. These perceptions are mythologized in the description of Hector and Andromache at the moment of their wedding in Song 44 of Sappho: the wedded couple are called $\{158 \mid 159\}$ i]keloi theoi[s (line 21) and theoeikeloi (line 34), and both these words mean 'looking like the gods'. ${ }^{11}$

\footnotetext{
${ }^{9}$ Nagy 2007:28, with further references.

${ }^{10}$ Nagy 2007:27-28.

${ }^{11}$ Nagy 2007:28.
} 
This idea of 'looking like the gods' in the context of a ritual is evident in the Homeric usages of homoios (ónoĩo) in situations where a hero emerges from a ritual bath in a sacred basin called the asaminthos. Here are the relevant passages (numbers 12 and 13):

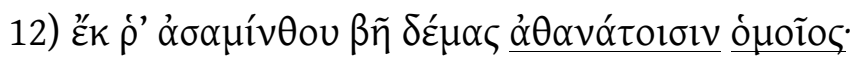

$\mathrm{He}[=$ Telemachus] emerged from the asaminthos, looking like [homoios] the immortals in size.

Odyssey iii 468

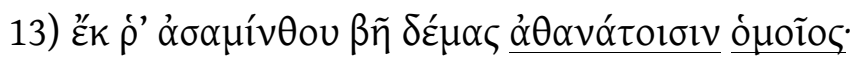

$\mathrm{He}[=$ Odysseus] emerged from the asaminthos, looking like [homoios] the immortals in size.

Odyssey xxiii 163

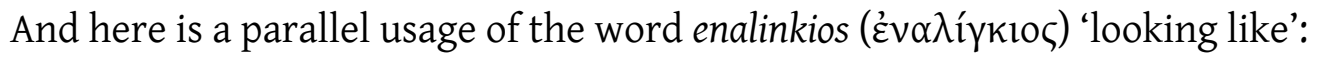

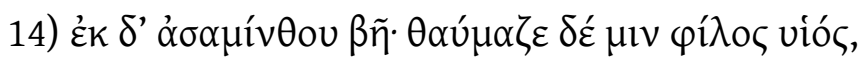

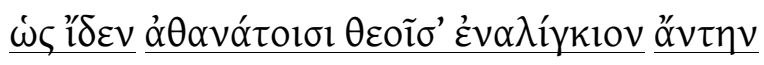

And he [= Odysseus] emerged from the asaminthos. His dear son [= Telemachus] marveled at him, when he saw him, face to face, looking like [enalinkios] the immortal gods.

Odyssey xxiv 370-371

In the example that we have just seen (number 14), the visual aspect of the simile is made explicit with the phrasing $\dot{\omega} \varsigma$ îd $\delta v . .$. óv $v \tau v$ 'when he [= Telemachus] saw him [= Odysseus], face 
to face'. In this example, then, Odysseus is quite literally 'looking like' the gods, as expressed by the adjective enalinkios.

In the next example, it is the adjective homoios that expresses the idea that Odysseus is 'looking like' the gods when Telemachus sees him, face to face. In this case, the divine looks of Odysseus are caused not by a ritual bath in the asaminthos but by direct physical contact with the goddess Athena herself: $\{159 \mid 160\}$

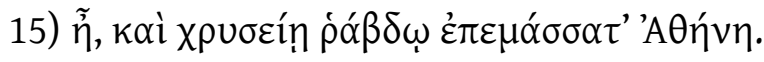

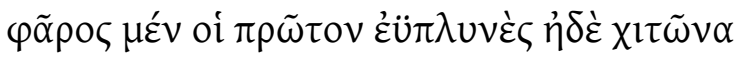

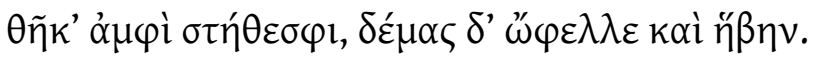

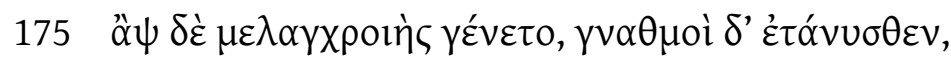

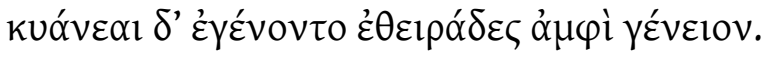

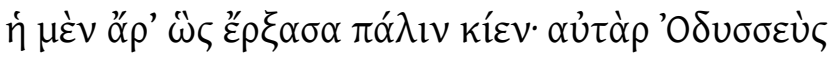

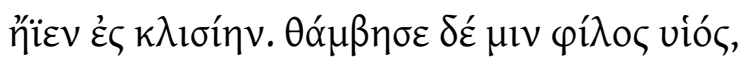

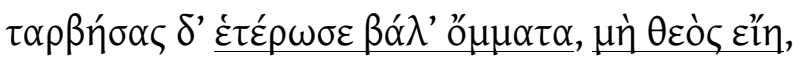

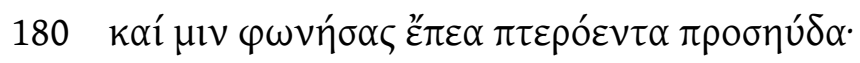

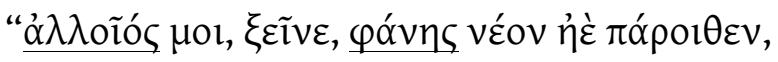

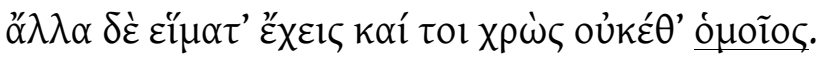

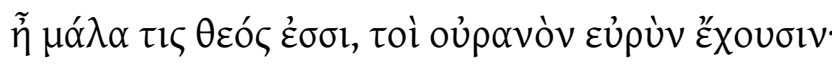

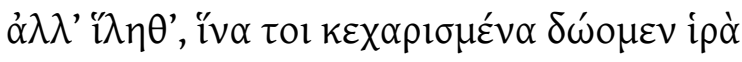

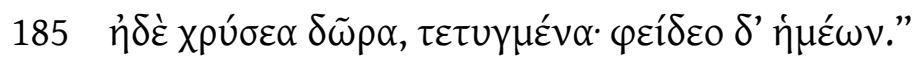

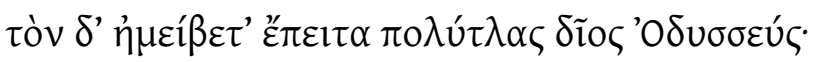

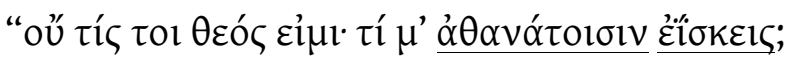

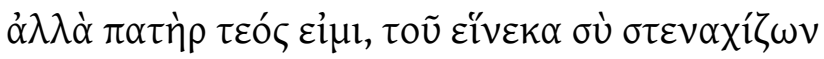

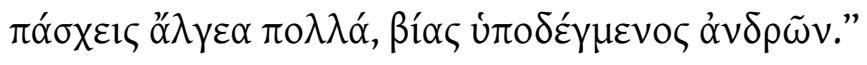




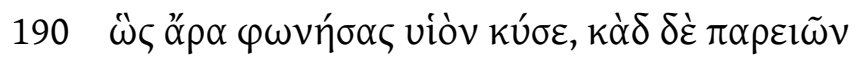

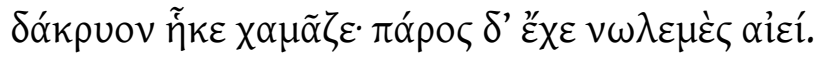

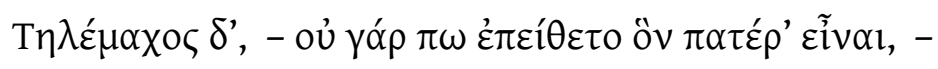

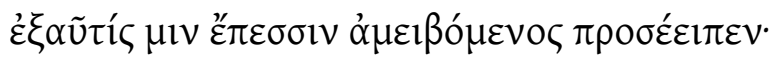

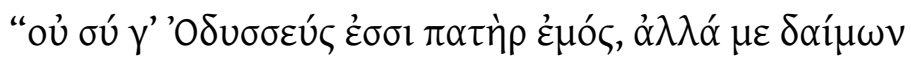

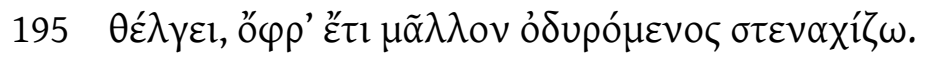

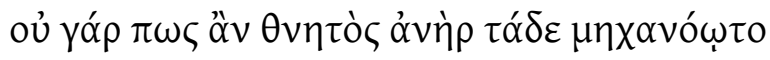

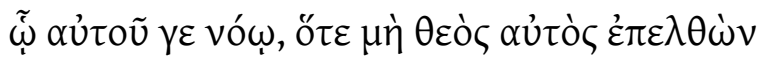

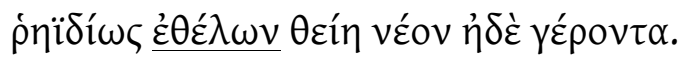

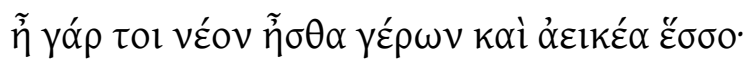

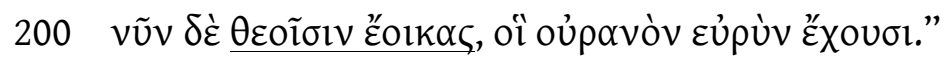

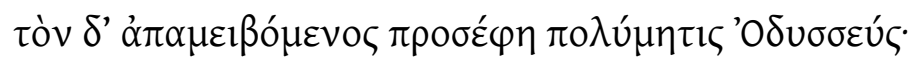

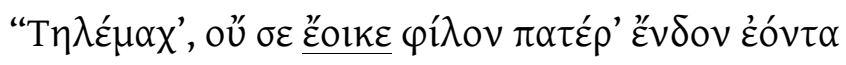

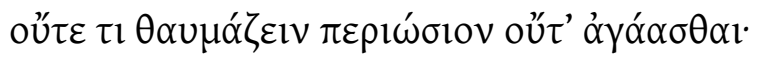

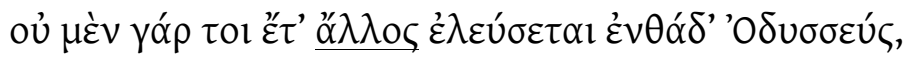

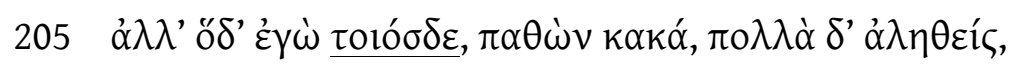

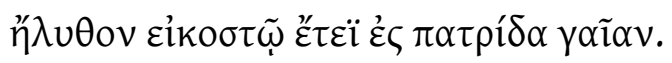

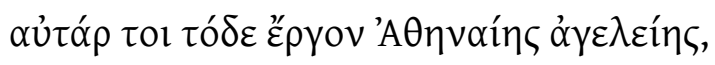

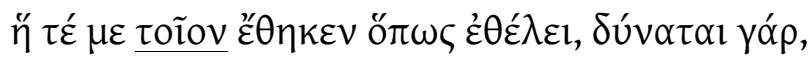

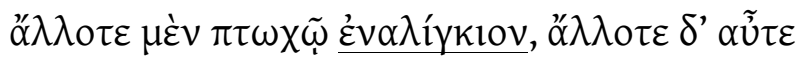

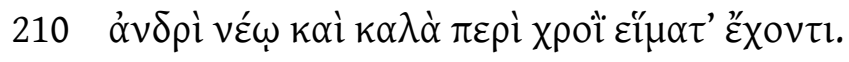

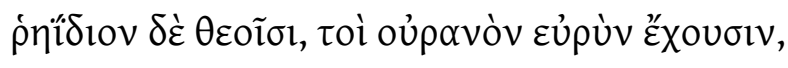

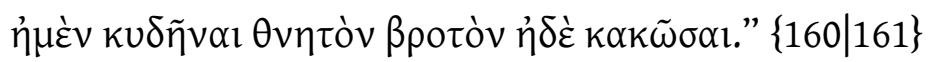


So spoke Athena, and she touched him [= Odysseus] with her golden wand.

First she made his mantle and his tunic to be cleanly washed,

she made it be that way, what he was wearing over his chest, and she augmented his size and his youthfulness.

175 His tan complexion came back, and his jaws got firmed up, and dark again became the beard around his chin.

Then she [= Athena], having done her work, went back where she came from, while

Odysseus headed for the shelter. His dear son [= Telemachus] marveled at him, and, in his amazement, he [= Telemachus] cast his gaze away from him, in another direction, fearing that he $[=$ Odysseus $]$ might be a god. 180 And he [= Telemachus] addressed him [= Odysseus], speaking winged words:

"As a different kind of person [alloios], stranger, have you appeared [phainesthai] to me just now, different than before.

You have different clothes and your complexion is no longer the same kind [homoios].

You must be some god, one of those gods who hold the wide sky.

So be gracious, in order that we may give you pleasing sacrifices 185 and golden gifts of good workmanship. Have mercy on us." And he [= Telemachus] was answered then by the one who suffered many things, the radiant Odysseus:

"I am not some god. Why do you liken [eïskein] me to the immortals?

But I am your father, for whom you mourn and suffer many pains, enduring the violent acts of men." 
190 Having said these things, he kissed his son and let fall from his cheeks

a tear, letting it fall to the ground. Until then he had persisted in showing no sign of pity.

And Telemachus, since he was not yet convinced that he [= Odysseus] was his father,

once again addressed him with words in reply:

"You are not Odysseus my father. Instead, some superhuman force

195 is enchanting me, and it makes me weep and mourn even more.

I say this because no mortal man could craft these things that are happening to me,

no mortal could do these things by way of his own devising, unless a god comes in person

and, if he so wishes, easily makes someone a young man or makes him an old man. $\{161 \mid 162\}$

Why, just a little while ago you were an old man wearing unseemly clothes, 200 but now you look like [= perfect of eïskein] the gods who hold the wide sky."

He was answered by Odysseus, the one with many kinds of craft, who addressed him thus:

"Telemachus, it does not seem right [= perfect of eïskein] for you to be amazed at your father who is right here inside [the shelter], for you to be amazed too much or to feel overwhelmed.

There will never again be some different [allos] person who comes here, some different Odysseus, 
205 but here I am such [toiosde] as I am. I have had many bad things happen to me. I have been detoured in many different ways.

But now I am here, having come back in the twentieth year to the land of my ancestors.

I tell you, this was the work of Athena, the giver of prizes, who has made me be such [toios] as she wants me to be, for she has the power. One moment, she has made me to be looking like [enalinkios] a beggar, and then, the next moment, 210 like a young man who has beautiful clothes covering his complexion. It is easy for the gods, who hold the wide sky, to make a mortal man become exalted with radiance or to debase him.

Odyssey xvi 172-212

In this example (number 15), we see that Odysseus no longer looks the same when his complexion is changed by the goddess. His complexion is no longer homoios (ónoĩoc) 'the same kind' (verse 182). That is why he no longer looks the same. Now he looks different. He is now a different kind of person. At the beginning of this essay, I noted that alloios ( $\dot{\alpha} \lambda \lambda_{\text {oinoc) ' } a}$ different kind' is the opposite of homoios (ouoĩoৎ) 'the same kind'. In the example I have just quoted, we see this meaning of alloios 'a different kind' in action (verse 181). I also noted that

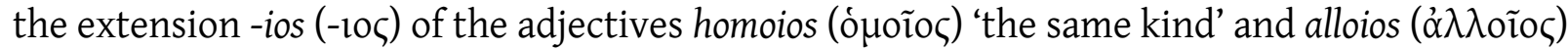
'a different kind' is parallel to the extension -ios (-10૬) of the adjectives hoios (oíoc) 'what kind'

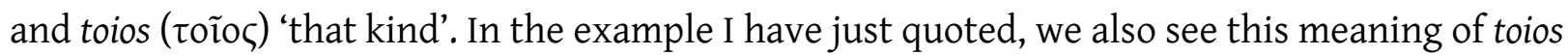
'that kind' in action (verses 205, 208).

In this same example (number 15), Odysseus looks like an old man or looks like a young man, whatever a divinity may wish (verse 198). But when he looks like a young man for 
Telemachus to see, his son needs to avert his eyes because he sees what he sees (verse 179). What he sees is that Odysseus at that moment looks not only like a $\{162 \mid 163\}$ young man but also like a divinity. When Odysseus asks his son, 'Why do you liken [eïskein] me to the immortals' (verse 187), Telemachus can rightly answer: 'but now you look like [= perfect of eïkein] the gods who hold the wide sky' (verse 200). And, in terms of the ritual transformation of Odysseus by way of a sacred bath in an asaminthos or by way of a sacred contact with the wand of the goddess Athena herself, this mortal not only looks like one of the gods but he actually becomes a god in the ritual moment marked by the similes that liken him to the god. I offer at this point this general formulation: for a mortal to appear like an immortal to other mortals is to become a divinity in a ritual moment of epiphany - as marked by the similes that make mortals equal to divinities in that ritual moment.

Similarly, when the divine Muses so wish, words that appear to be true can really be true:

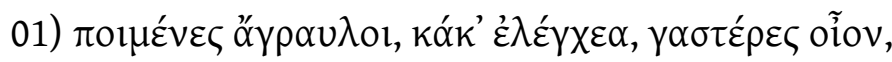

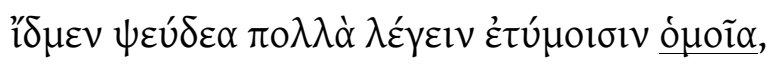

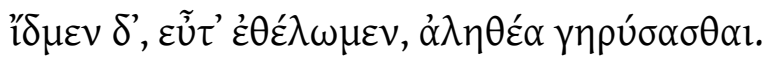

Shepherds camping in the fields, base objects of reproach, mere bellies! We know how to say many deceptive things looking like [homoia] genuine things, but we also know how, whenever we wish it, to proclaim things that are true.

Hesiodic Theogony 26-28

In this example, what is deceptive is not that some things are 'looking like' other things. Rather, what is deceptive is that pseudea 'deceptive things' can look like real things. And even these deceptive things that look like real things can still be equal to real things, the same as 
real things. As we saw earlier, for example, Odysseus is really 'equal to the immortals' when he looks like an immortal in ritual contexts. If Telemachus is deceived by the looks of Odysseus in such contexts, then the deception is in the eyes of the uninitiated beholder who cannot yet distinguish between what is deceptive and what is real. Similarly in the Hesiodic Theogony, the figure of Hesiod has been such an uninitiated beholder before his poetic initiation into the art of the Muses. After his initiation, however, he can now envision what is real even when he beholds things that can be deceptive. ${ }^{12}\{163 \mid 164\}$

The same principle holds whenever Odysseus utters words to be envisioned only by those who have already been initiated into the art of the Muses of poetry:

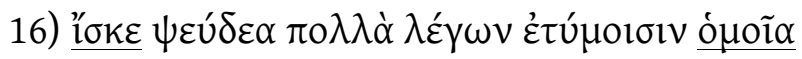

He made likenesses [eïskein], saying many deceptive things looking like [homoia] genuine things.

Odyssey xix 203

In this example as well, what is deceptive is not that some things are 'looking like' other things. Rather, what is deceptive is that pseudea 'deceptive things' look like real things. And, once again, even these deceptive things that look like real things can still be equal to real things - the same as real things as seen by those who are initiated into the art of the Muses. ${ }^{13}$

The art of the Muses is the art of poetic imagination, which can make even deceptive things look like real things, be equal to real things, be the same as real things.

\footnotetext{
${ }^{12}$ On the theme of Hesiod's poetic initiation, I have more to say, with further references, in Nagy 2009.

${ }^{13}$ My interpretation of Odyssey xix 203 follows my analysis in Nagy 1990:44, 274. I consider my current translation, however, to be an improvement on the one I offered in that analysis: 'He spoke, assimilating many falsehoods to make them look like genuine things'.
} 
Such is the art that is borrowed by the alluring figure of Helen when she makes her voice

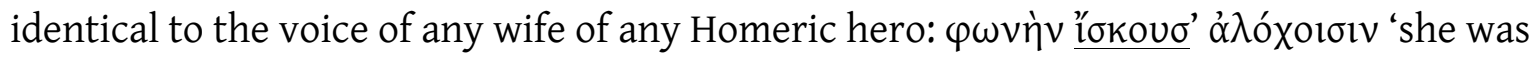
making her voice like [eïskein] the voices of their wives' (Odyssey iv 279). Her voice, borrowed from the poetry of the Muses, has the power of conjuring the voices of the wives themselves. And, by extension, her poetic voice has the power of conjuring the very images of the wives.

True, Helen means to deceive, but her deceptive words in this narrative frame are the same as the real words of Homeric poetry in the overall narrative frame of that poetry - real words that activate visions of the real things of Homeric poetry. These real things are whatever is real for this poetry, which is figured as true. For Homeric poetry, whatever is divinely true can contain deceptions and still be true.

A salient example of such deception contained within the overall framework of divine truth is the moment when the goddess Aphrodite appears in an epiphany to the young hero Anchises, looking like a young girl: $\{164 \mid 165\}$

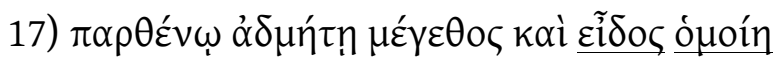

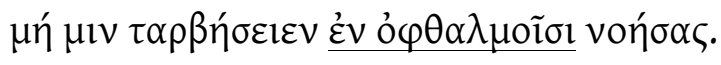

Like a virgin unwed, in size and in looks [eidos], that is what she [= Aphrodite] was looking like [homoiē].

She did not want him to get alarmed when he with his own eyes perceived her.

Homeric Hymn to Aphrodite 82-83 Later on in the same narrative, when Aphrodite reveals herself as a goddess to Anchises, she says:

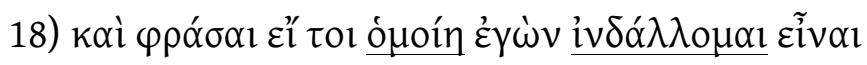




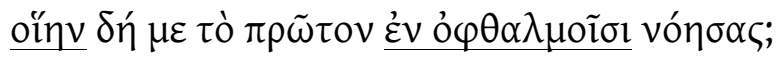

And now you should take note whether I look like [indallesthai] the same kind of person [homoiē]

as the kind of person [hoiē] you first saw when with your own eyes you perceived me.

Homeric Hymn to Aphrodite 178-179

In response, Anchises claims that he knew all along that the beautiful young girl was Aphrodite:

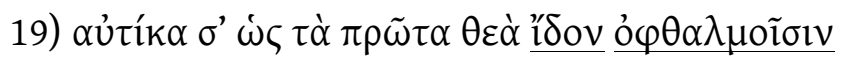
$\varepsilon^{\prime} \gamma \nu \omega \nu \stackrel{\omega}{\omega} \theta \varepsilon \dot{\varsigma} \varsigma \tilde{\eta} \sigma \theta \alpha$.

The moment I saw you, goddess, with my own eyes I just knew that you were a goddess.

Homeric Hymn to Aphrodite 185-186 Whether or not Anchises knew all along that the girl was Aphrodite, it is all in the eyes of the mortal viewer, the sameness or the difference. But the divine vision, either way, is true in the long run, and this truth is mediated by the poetic art of the Muses.

Despite the seemingly easy equivalence of immortals and mortals in these last three examples, the fundamental difference between them remains a fatally serious difficulty, as we see elsewhere in the ominous words of Apollo when the god warns the reckless hero Diomedes:

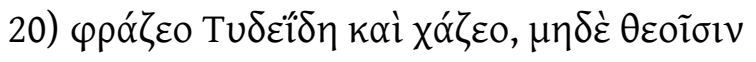

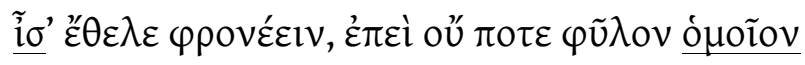




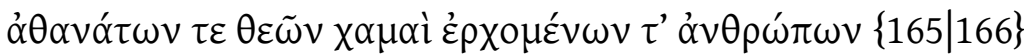

Take note, son of Tydeus, and draw back. Do not try, with regard to the gods, to think thoughts equal [isa] to their thoughts, since our kind and your kind are not at all the same [homoion],

I mean, the lineage of the immortal gods and the lineage of humans who walk the earth.

Iliad V 440-442

I bring this essay to a close by showing three more examples of similes activated by the adjective homoios:

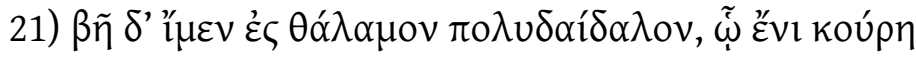

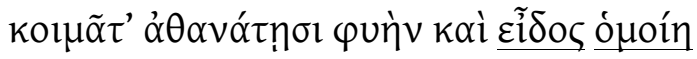

She [= the goddess Athena] came into the private chamber, with its many adornments, where the girl [= Nausikaa] was sleeping. Like the immortal goddesses, in shape and in looks [eidos], she [= Nausikaa] was looking like [homoiē] them.

Odyssey vi 15-16

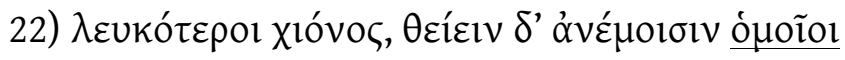

And they [= the horses of Rhesus] were whiter than snow, and they were like [homoioi] the winds, the way they ran.

Iliad X 437 


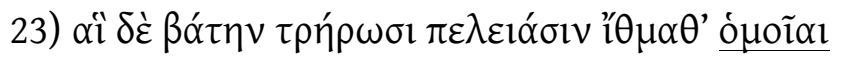

And they [= the goddesses Hera and Athena] went along, like [homoiai] tremulous doves, the way they went.

Iliad V 778

All three examples show the power of poetic visualization, even though only the first of the three is explicit in expressing the use of eyesight in the visualization. In a simile, when something is like something else, the likeness does not have to be a permanent resemblance that links one noun visually with another noun. The likeness can be a momentary resemblance between any overall visualization and any other overall visualization. For example, it is not that Hera and Athena always look like tremulous doves. ${ }^{14}$ But there are moments when they can be envisioned that way. One such moment is when you see them in motion, when you see them fluttering like tremulous doves. $\{166 \mid 167\}$

In conclusion, I propose to say more generally what I said earlier with specific reference to Odyssey xvi 172-212 (number 15 in my repertory of examples). When anyone in Homeric narrative is deceived by the looks of something or someone, such deception is in the eyes of the uninitiated beholder who cannot distinguish between what is deceptive and what is real. Similarly in the Hesiodic Theogony, as I have argued, the figure of Hesiod is such an uninitiated beholder before his poetic initiation into the art of the Muses. After his initiation, as I have also argued, Hesiod can envision what is real even when he beholds those things that may be deceptive. In translating

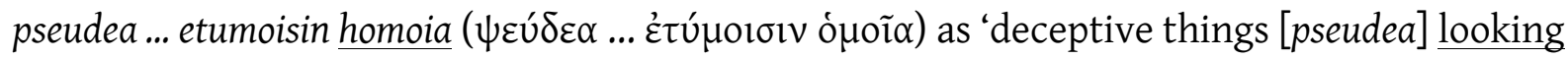
like [homoia] genuine [etuma] things' at verse 27 of the Theogony, I highlight the idea that

\footnotetext{
${ }^{14}$ With reference to this example as well as to others I have already analyzed, my interpretation differs from that of Heiden 2007.
} 
whatever things look like etuma 'genuine things' in one given localized poetic version could look like pseudea 'deceptive things' in a rival localized poetic version; each locale could have its own poetic version, and all such local versions show relative truth values - in comparison to the absolutized truth that is signaled by the word alethea 'true things' at verse $28 .{ }^{15}$

\section{Bibliography}

Heiden, B. 2007. “The Muses' Uncanny Lies: Hesiod, Theogony 27 and its translators." American Journal of Philology 128:153-175.

Blaise, F, Judet de la Combe, P., and Rousseau, P. eds. 1996. Le Métier du Mythe: Lectures d'Hésiode. Cahiers de Philologie 16. Lille.

Chantraine, P. 2009. Dictionnaire étymologique de la langue grecque: histoire des mots (ed. J. Taillardat, O. Masson, and J.-L. Perpillou), with a supplement Chroniques d'étymologie grecque 1-10 (ed. A. Blanc, Ch. de Lamberterie, and J.-L. Perpillou). Paris.

Leclerc, M.-C. 1993. La Parole chez Hésiode. Paris.

Nagy, G. 1990. Greek Mythology and Poetics. Ithaca, N.Y.

Nagy, G. 2007. "Lyric and Greek Myth.” The Cambridge Companion to Greek Mythology (ed. R. D. Woodard) 19-51. Cambridge.

Nagy, G. 2009. "Hesiod and the Ancient Biographical Traditions." Brill Companion to Hesiod (ed. F. Montanari, A. Rengakos, and Ch. Tsagalis) 271-311. Leiden.

Pucci, P. 1977. Hesiod and the Language of Poetry. Baltimore.

Pucci, P. 2007. ed. (with commentary). Inno alle Muse (Esiodo, Teogonia, 1-115). Pisa / Rome.

\footnotetext{
${ }^{15}$ Nagy 1990:44-46; at p. 44 I compare the use of pseudea 'deceptive things' in the Homeric Odyssey with reference to localized poetic versions of a "Cretan odyssey" as narrated by the disguised Odysseus in the form of "Cretan lies."
} 